\title{
Effect of Microcystis aeruginosa blooming on the production of Nile tilapia (Oreochromis niloticus) in fish ponds Mostafa A. I. Elgammal ${ }^{1}$ Ashraf A. Ramadan ${ }^{2}$ \\ 1- Fish limnology Department 2- Fish Genetics Department Central Laboratory for Aquaculture Research, Abbassa, Abou- Hammad, Sharkia, Egypt. Corresponding researcher e-mail address: drelgammal@yahoo.com
}

\begin{abstract}
Reasons for low fish farm production at Eltel El-kabeer area, Ismailia Governorate were unknown. At the concerned area, fish survival rates have been dropped to reach less than $10 \%$ for several consecutive years. Some of the conducted studies, concerning the high mortality rates in the concerned area, claimed that that phenomenon was initially referred to cyanobacterium blooming (Microcystis aeruginosa) thought to be ingested by fish during feeding, or assimilated through gills during breathing.

Twelve earthen ponds (each of $2000 \mathrm{~m}^{2}$ area, 100-120 $\mathrm{cm}$ water depth, fertilized by $125 \mathrm{~kg}$ chicken manure / pond / week for a period of 16 weeks, and stocked with 5000 Nile tilapia fry with a weight ranged 5-7 gm) were used in the study and were divided equally into two studied groups. The first pond group was full of Microcystis aeruginosa bloom, while the second pond group was free of Microcystis aeruginosa bloom. Fish were stocked in the two previously mentioned studied pond groups, fed on feeding rate at $3 \%$ of live body weight. Commercial floating fish diet with $25 \%$ protein content was used in fish feeding. Physicochemical parameters, plankton population, fish survival, fish production, and toxicity test for different fish size $(5,20,50,150$ grams). In addition, Artemia also were studied.
\end{abstract}

There was a significant difference between the two studied pond groups concerning all physical and chemical water characteristics investigated. Those investigated water characteristics were: dissolved oxygen, visibility, salinity, total suspended solid (TSS), alkalinity, total phosphorus and Ammonium $\left(\mathrm{NH}_{4}\right)$. On the other hand, there was no significant difference between the two studied pond groups concerning each of temperature, $\mathrm{pH}$, electric conductivity (EC), Hardness, nitrate $\left(\mathrm{NO}_{3}\right)$ ammonium $\left(\mathrm{NH}_{3}\right)$ and chlorophyll "a". In general, all investigated values were within the suitable range for tilapia growth.

The abundance of phytoplankton in number was highly significant in the first research pond group concerning each of Cyanophyta, Euglenophyta, and Microcystis aeruginosa in blooming, and was not significant in Baciloarophyta and Chlorophyta. In addition, Zooplankton was significant in numbers concerning Cladocera, Rotifers and Copepoda and was not significant in total zooplankton 
number. Fish and Artemia exposed to pond with Microcystis blooming died within 24 hours.

The research drew the attention towards conducting more future research studies in this concern as a way to control the toxic algae of Microcystis aeruginosa in fish ponds.

Key words: Microcystis aeruginosa, fish production, water quality, phytoplankton, zooplankton.

\section{INTRODUCTION}

Bloom of Cyanobacterium Microcystis aeruginosa is a ubiquitous phenomenon in eutrophic lakes, fish ponds, reservoirs and polluted water in many countries of the world. Many strains of Microcystis are known to produce Cyanobacterial hepatotoxins called microcystin. The toxin, a soluble peptide, is lethal to many kinds of aquatic organisms and damages zooplankton, fish, and also liver of higher animals (Gan et al., 2010; Penaloza et al., 1990; Sivonen, 1990; Watanabe et al., 1989).

There has been an apparent increase in the occurrence of harmful algal blooms (Hallegraef, 1993; Newman \& Barrett, 1993, Geng \& Xie 2008; Soares et al., 2010). In general, there are three classes of algal blooms which are ranked according to their level of toxicity: (1) those which are fundamentally harmless until their breakdown by certain bacteria deprives fish and invertebrates of oxygen; (2) those which produce toxins which are accumulated through the food chain resulting in various types of shellfish poisoning in humans; (3) those which produce toxins which are non-toxic to humans but are toxic to fish and invertebrates.. Although presence of the previously mentioned algal blooms may be noticed throughout the year in water bodies, they proliferate abundantly from summer to autumn (Carmichael, 1995).

Among some important bloom forming Cyanobacteria came those of Anacystis,Anabaena, phanizomenon, Rivularia and Microcystis, and others. Among the Microcystis, the cyanobacaterium is considered the most widespread and frequently encountered organism. It is well known with its ability to destroy the pristine quality of water and cause many problems such as occurrence of nasty odor, fish kill, deterioration of recreational worth and clogging of filter in water supply system. In addition, it also releases toxins such as microcystin (Carmichael and An, 1999) which is toxic to each of fish, aquatic invertebrates, domestic animals and human beings. The development of Cyanobacterium bloom may also be partly explained due to unpalatability since Microcystis are hardly grazed upon by zooplanktons. The ability of Microcystis species to photosynthesize at rates higher than green alga may also facilitate the dominance of Microcystis in water bodies (Osami et al., 1994). Field and laboratory studies indicated that grazing by some zooplankton can be disrupted by toxic Cyanobacteria (Lampert, 1987; De Bernardi; and Giussani, 1990; Sellner et al., 1993; Boon et al., 1994; Christoffersen, 
1996; Rohrlack et al., 1999; Paerl et al., 2001; Ghadouani et al., 2003).

In many systems which experience dense and/or toxic blooms, mesozooplankton $(>200$ $\mathrm{mm}$ ) such as Cladocerans and Copepods can be impacted, experiencing reduced feeding, reduced food assimilation or even mortality (Paerl et al., 2001 and Ghadouani et al., 2003). Concerning degree of zooplankton graze, Cyanobacteria can be influenced by many factors including toxin concentrations, strains of Cyanobacteria species, species of zooplankton, and various environmental conditions (Paerl, 1988; Sellner et al., 1993; Boon et al., 1994; Christoffersen, 1996).

Recent studies of field isolated Daphnia have shown that individuals isolated from eutrophic environments, which are presumed to have been chronically exposed to toxic Cyanobacteria, are better in its ablity to graze and grow in the presence of cultures of toxic Microcystis sp. than individuals that have not been exposed to blooms (Hairston et al., 2001; Sarnelle \& Wilson, 2005).

In general, those studies indicated that Daphnia are able to adapt to the presence of toxic Cyanobacteria, others have found these grazers were not able to graze on Cyanobacteria, even when frequently exposed (Walls et al., 1997). It was suggested that microzooplankton (20-200 mm) may graze on toxic Cyanobacteria (Paerl et al., 2001 and Leonard \& Paerl, 2005), and microzooplankton grazing rates on toxic Cyanobacteria have yet to be quantified. Sublethal effects resulting from microcystin exposure include liver damage in carp growing in New Zealand lakes (Carbis, et al., 1997) and decreased opercula movement in tilapia fed toxic Microcystis (Keshavanath, et al., 1994).

The main objectives of the research were identified as the following:

1- To determine causes of fish mortality increase in some fish farms that may lead to low fish production.

2- To define effect of Microcystis aeruginosa on the production of Nile tilapia (Oreochromis niloticus) in fish ponds.

\section{MATERIALS AND METHODS}

The research was conducted in Eltal El-Kebeer area, Ismailia Governorate / Egypt. Twelve earthen ponds, divided into equal pond groups (6 ponds each) each of 2000 $\mathrm{m}^{2}$ total area, of were used in carrying out the research. Ponds were drained, cleaned and supplied with fresh water from Ismailia canal branched from Nile River. water depth in those research ponds ranged $(100-120 \mathrm{~cm})$, with a stable average water depth of approximately one meter. In those research pond groups, supply and drainage pipes were equipped with nylon screen to prevent fish escape and / or entry. The first pond group (filled with Microcystis aeruginosa bloomings), the second groups (free from Microcystis aeruginosa). The study started from 15 April till 17 October 2010.

All ponds, in the two studied / research groups, were fertilized each 
by $\quad 125 \quad \mathrm{~kg} \quad$ chicken manure/pond/week and after 16 weeks, the commercial floating diet contains $25 \%$ protein was used to feed the fish in two groups $3 \%$ live body weight. The used stocking rate for each studied pond was 5000 Nile tilapia (Oreochromis niloticus) fry, mono sex, with an average weight ranged 5-7 grams. The stocked fish and monthly at rigidly determined pond sites. Mean values of the different parameters, under examination, were expressed as changes during the conducted research period (table 1). A column sampler constructed from a PVC pipe (5-cm diameter, 1.5-m long) was used to collect water samples for phytoplankton, total suspended solids

Table 1: Methods of analysis of Chicken manure used to fertilize the experimental earthen ponds and chemical, physical and plankton properties of water fish ponds

\begin{tabular}{|c|c|c|c|}
\hline Parameters & Time & Method & Source \\
\hline \multicolumn{4}{|c|}{ Chicken manure analyses } \\
\hline Dry matter & Every batch of manure & Oven dried $\left(80^{\circ} \mathrm{C}\right.$ overnight $)$ & APHA (1985) \\
\hline Total Kjeldahl Nitrogen & Every batch of manure & Modified Micro-Kjeldahl method & Yoshida et al., (1976) \\
\hline Total phosphorus & Every batch of manure & Acid digestion & Yoshida et al., (1976) \\
\hline Potassium & Every batch of manure & spectrophotometers & (AOAC 1990) \\
\hline Total ash & Every batch of manure & Ignition at $600^{\circ} \mathrm{C}$ for 2 hours & APHA (1985) \\
\hline Organic carbon & Every batch of manure & $\%$ Carbon $=(100-\operatorname{ash} \%) / 1.8$ & Golueke (1977) \\
\hline \multicolumn{4}{|c|}{ water Pond analysis } \\
\hline Total suspended solids (TSS) & Every week & Oven drying (105oC for $4 \mathrm{~h})$ & APHA (1985 \\
\hline Total alkalinity & Every 2 weeks & Titration with o. $1 \mathrm{~N}$ sulfuric acid & APHA (1985 \\
\hline Total hardness & Every 2 weeks & Titration with EDTA & APHA (1985) \\
\hline Total phosphorus & Every week & Acid digestion & Yoshida et al., (1976) \\
\hline Nitrate $\mathrm{mg} / \mathrm{l} \mathrm{NO}_{3}$ & Every week & Cadmium reduction method & Boyd (1992) \\
\hline Total ammonia mg/l $\left(\mathrm{NH}_{4}, \mathrm{NH}_{3}\right)$ & Every week & Indophenol or Phenat method & Boyd (1992) \\
\hline Temperature \& DO measurement & Daily 5 day/week & DO meter & YSI (model 58) \\
\hline $\mathrm{pH}$ & Every week & $\mathrm{pH}$ meter & Corning ( model 345) \\
\hline Salinity\&(EC Water Conductivity) & Every week & Conductivity meter & YSI (model 33) \\
\hline Chlorophyll a & Every week & Acetone extraction method & APHA (1985 \\
\hline Phytoplankton counts & Every 2 weeks & Counting by using a microscope & APHA (1985) \\
\hline Zooplankton counts & Every 2 weeks & Counting by using a microscope & APHA (1985) \\
\hline
\end{tabular}

were harvested and weighed after 24 weeks. The obtained measurements came in accordance with the following:

a- $\quad$ Fish survival rate $=$ (initial numbers of fish stocked - numbers of dead fish / initial numbers of fish stock) 100

b- Fish production $(\mathrm{kg})=$ harvested fish weight $(\mathrm{kg})$

In addition, physicochemical and biological properties of water ponds were studied throughout the predetermined investigation periods, samples were taken daily, weekly
(TSS). A stick sampler, with an attached $300 \mathrm{ml}$ biological oxygen demand bottle, was used in collecting water samples from a depth of $10 \mathrm{~cm}$ for all other parameters. Mean individual final weight, daily weight gain, yield and survival data were analyzed using analysis of variance, ANOVA (Zar, 1984). Significant differences were at an alpha level of 0.05 .

Fish exposed to water pond with Microcystis aeruginosa bloom

Laboratory reared fish. (5, 20,50,150 gm) were exposed to water from the blooming ponds by gavages 
and intra-peritoneal (IP) injection (Carbis, et al., 1996) with only an exception in using fish size with 5 grams each and they were exposed to bloom water pond only. Pond water blooming was concentrated 15-fold by centrifugation at $100 \mathrm{~g}$ for $10 \mathrm{~min}$. The pellet was resuspended, triturated by mortar and pestle, and $0.5 \mathrm{ml}$ of this suspension was administered intraperitoneally (n. 5) and orally (n. 5). Fish were held in 25 liter aquaria containing dechlorination tap water under static conditions and observed for 48 hours. In each case, appropriate dechlorination water controls were utilized. Fish died following these procedures were subjected to similar diagnostic testing as described above.

\section{Artemia bioassay}

\section{Brine shrimp medium (BSM) stock solution,}

BSM stock solution composed of sodium chloride $(\mathrm{NaCl}) 300 \mathrm{~g}$, Calcium chloride dehydrate $(\mathrm{CaCl}$ $\left.2 \mathrm{H}_{2} \mathrm{O}\right) 3 \mathrm{~g}$, Magnesium chloride hexhydrate $\left(\mathrm{MgCl} 2.6 \quad \mathrm{H}_{2} \mathrm{O}\right) \quad 15 \mathrm{~g}$, Magnesium sulphate heptahydrate $\left(\mathrm{MgSO}_{4} .7 \mathrm{H}_{2} \mathrm{O}\right) \quad 5 \mathrm{~g}$, Potasium chloride $(\mathrm{KCl}) 8 \mathrm{~g}$, Glycine $60 \mathrm{~g}$, Disodium glycerophosphate $30 \mathrm{~g}$. All the stock solution chemicals were dissolved in 1.25 liters of distilled water dissolved each chemical separately and kept in brown glass bottle in refrigerator $\left(-4^{\circ} \mathrm{C}\right)$

Brine shrimp eggs were supplied by Ocean Star International Inc. (Snowville, USA). Larvae were used within just a day after hatching. Following extraction of lyophilized cell masses $(50 \mathrm{mg}$ ) of Microcystis aeruginosa with methanol, the extract was evaporated to dryness in a vacuum. The dried extract was dissolved in $250 \mathrm{ml}$ filtered brine shrimp medium (BSM) stock solution, reaching a concentration as $200 \mathrm{mg} / \mathrm{ml}$ in terms of lyophilized cell masses, then further diluted with $\mathrm{BSM}$ to give five concentrations of 100, 50, 20, 10, and $2 \mathrm{mg} / \mathrm{ml}$. Assays were performed on Petri dish $(5 \mathrm{~cm}$ diameter) with 10 20 brine shrimp larvae in $5 \mathrm{ml}$ of BSM per dish. The brine shrimp larvae in each dish were tested using $5 \mathrm{ml}$ per concentration level of extract. They were observed for $24 \mathrm{~h}$ to calculate mortality (Meyer et al., 1982).

The toxicity threshold concentration, expressed as dry weight of Microcystis aeruginosa mass per milliliter of BSM, was defined as the lowest concentration that kills all tested brine shrimp within 24 hours. Each test was run in triplicate, and BSM was used as the control.

\section{RESULTS AND DISCUSSION}

Effective water management in fishponds is one of the most important factors contributing to the success of fish culture, reducing the occurrence of fish disease, enhancing better fish growth, and increasing survival

The obtained analyses of organic fertilizers (chicken litter before and through the application), total average values of dry matter; total nitrogen; phosphorus and potassium, were $89.52 ; 1.64 ; 1.38$ and $0.76 \%$ respectively.

Physicochemical investigation for water fish ponds showed no significant differences in water temperature between the first group 
ponds and the second group ponds (table 2). The result provided an indicator implied that the blooming of Microcystis aeruginosa had no effect on water temperature in the ponds and that the effect of air temperature is critical factor in that aspect (Boyd, 1990).

The Secchi disk visibility in water for the first group ponds was decreased significantly $(18.08 \pm 1.4$ $\mathrm{cm})$ when compared to unaffected ponds $(25.13 \pm 1.5 \mathrm{~cm})$. While the dissolved oxygen concentration in the first group ponds $(9.6 \pm 1.43$ $\mathrm{mg} / \mathrm{l})$ was increased significantly than the second group ponds (7.8 \pm $1.4 \mathrm{mg} / \mathrm{l})$. This may be explained as a result of high abundance of phytoplankton and blooming of $M$. aeruginosa in the first group ponds, the high concentration of dissolved oxygen in parallel with the increased photosynthetic activity of phytoplankton population. In this respect, Talling (1986) reported that oxygen supersaturation, due to photosynthetic activity, is often recorded with abundant phytoplankton. In general, Secchi disk values and dissolved oxygen concentrations, recorded in first and second group ponds, were always higher than the critical minimum concentration for fish growth (Balarin \& Haller, 1982; Dianna et al., 1991).

Results presented (table 2 \& figure 1) Showed also no significant changes in water $\mathrm{pH}$ in first group ponds and second group ponds. This may be explained as a result of the limited amount of organic fertilizer which was not enough to affect the $\mathrm{pH}$ of the large water volumes directly, although the total numbers of phytoplankton was with no significant differences between the two groups. The $\mathrm{pH}$ was higher in first group ponds (fig.1) on June than the second group ponds, where the increase of blooming of $M$. aeruginosa on June led to an increase in the photosynthesis that involved the uptake of the carbon dioxide from the water by algae and increased the $\mathrm{pH}$ values (Boyd 1990; Abdalla 1997).

As shown in Table (2) and figure (1), Water alkalinity was significantly decreased in the first group $(258.33 \pm 16 \mathrm{mg} / \mathrm{l})$ ponds when compared to the second group ponds $(284.82 \pm 7 \mathrm{mg} / \mathrm{l})$; but total hardness was not significant between the first group ponds $(253 \pm 11 \mathrm{mg} / \mathrm{l})$ and the second group ponds (231 \pm $17 \mathrm{mg} / \mathrm{l})$. The obtained values for both total hardness and alkalinity were always suitable, or ideal, for microbial phytoplankton and fish growth (Krenkel \& Novotny, 1980; Piper et al., 1982).

The mean levels of ammonium$\mathrm{NH}_{4}$ and total phosphorus was decreased significantly in the first group than second group ponds as shown in (Table 2) which was in parallel with an increase in phytoplankton and blooming of $M$. aeruginosa because of phytoplankton uptake ammonium- $\mathrm{NH}_{4}$ and phosphorus for their growth (Boyd, 1992). The measured nitrate $\mathrm{NO}_{3}$ and $\mathrm{NH}_{3}$ in water fish ponds (table 2 and figure 1) indicated that there was no significant difference between the two groups. The salinity $(\mathrm{mg} / \mathrm{l})$ and total suspended solid $(\mathrm{mg} / \mathrm{l})$ were decreased significantly in the first 
group than the second group ponds. On the other hand, there was no significance difference between the two studied pond groups concerning electric conductivity (EC). .

Based upon the obtained results, range of all parameters was always good or ideal for water productivity and fish production (Boyd 1992; Khalil, 1990; Abdalla, 1997).

It was found (table 2 and figure 1) that there were no significant differences, concerning chlorophyll "a" concentration in water expressed in $\mu \mathrm{g} / \mathrm{l}$, between the two studied pond groups in all months of investigation (June and September were an exception). It was found that the first group ponds recorded higher values than the second group ponds (total averages were 88.48 \& $56.97 \mu \mathrm{g} / 1$. in first and second group ponds respectively). In addition, values of chlorophyll "a" were (141.9 \& 46.6 $\mu \mathrm{g} / \mathrm{l})$ on June and $(200.95$ \& $156.10 \mu \mathrm{g} / \mathrm{l})$ on September paralleled with abundance of phytoplankton and increase of the blooming of $M$. aeruginosa in those mentioned months. The obtained results came to confirm those of Boyd, (1990); Zhang, and Geng, (2011).

The different structures of plankton community might be due to different degrees of tolerance by different organisms to the available chemical and environment conditions, in addition to their differences in nutritional requirement and fish (planktivorous) utilization of some preferred species (Northcote, 1988)

In regard with different algal species in the two research groups of fish ponds belonged to Cyanophycophyta, Chlorophyta, Bacilarophyta and Euglenophyta, it was found that total count of phytoplankton in the first group ponds was more significant difference at $\mathrm{P}<0.05$ than the total numbers of phytoplankton in the second groups at most months of the research. The cyanophycophyta groups had more significant difference in first groups than the second groups $(\mathrm{P}<0.05)$. The percentage of $M$. aeruginosa in total phytoplankton in the first groups was higher than that of the second group. The higher percentage was recorded $83.6 \% \& 65.7 \%$ in June and September respectively, but the lowest percentage was in October with $18.7 \%$ for the first group ponds. The species was rarely found in second group ponds. The bloom appeared obviously on (8-15 June) and (18-22 September). Despite their presence may be noticed throughout the year in water bodies, they proliferate abundantly from summer to autumn. This also may occur as a reason for the toxicity of $M$. aeruginosa which causes an increase in the mortality of $O$. niloticus in the first groups and a decrease in the phytoplankton consumed by fish. This phenomenon caused due to the increased numbers of phytoplankton that appear as the phytoplankton blooming (Carmichael, 1995; Zhang, \& Geng, 2011).

The Euglinophycophyta was recorded the higher numbers in the first group ponds in parallel with the high numbers of $M$ aeruginosa. The blooming of Euglinophycophyta increased significantly in the first groups than second groups $(\mathrm{p}<0.006)$ 
through all period of research investigation (Table 3). On the other hand, there was no significant difference between the first groups and the second groups concerning numbers of Chlorophycophyta and Bacilarophyta (table 3). The difference in structures of phytoplankton communities within fish ponds in the two studied groups could be explained on basis of different degrees of tolerance for different categories of phytoplankton organisms to the present nutritional requirements (Hanson et al., 1987; Northcote, 1988)

Table 5 showed that the zooplankton obtained from water fish ponds in the two studied groups. The identified zooplankton species were those of rotifers, cladocera and copepoda. The obtained findings showed no significant difference between the two research pond groups regarding total count of zooplankton. The research results (table 4) indicated that there was a less significant difference in the first group ponds than the second group ponds in content of rotifer which may be explained as a positive correlation between the decreased phytoplankton numbers and the increase in $M$ aeruginosa numbers. The accrued finding confirmed that of Wylie and Currie (1991) and Qin and Culver (1992). On the other hand, the Cladocera and Copepoda numbers were significantly increased in the first group than second group which may be explained as Cladocera and Copepoda have the ability adapt to the presence of toxic Cyanobacteria (Walls et al., 1997; Trabeau et al., 2004). It was suggested that they may graze on toxic Cyanobacteria
(Paerl et al., 2001; Leonard \& Paerl, 2005; Zhang \& Geng, 2011),

It was indicated (table 6) that survival rate of $O$. niloticus was decreased significantly $(5.5 \%)$ in the first group ponds in comparison with the second group ponds (80.36\%), and the lower fish production $(31.08$ $\mathrm{kg}$ ) in the first group ponds versus the second group ponds $(560.75 \mathrm{~kg})$. The lower survival rates and production paralleled with the blooming of $M$ aeriginosa in the first group ponds.

Although fish injected by $M$ aeriginosa died within 48 hours, the gavages fish didn't die through using the same concentration of $M$ aeriginosa. Dead fish was negative for bacterial pathogens.

The percentage of $\mathrm{LC}_{50}$ death of Artemia at 24 hours exposed to the toxicity threshold concentration, expressed as dry weight of $M$ aeriginosa as tabulated in table (7) was death in all concentration except that of $2 \mathrm{mg} / \mathrm{ml}$. This may be explained as an effect of toxicity $M$ aeriginosa for both of fish and Artemia. The results came in harmony with Keshavanath, et al., (1994); Lahti et al.(1995); Vezie et al., (1996) that stated toxicity of Cyanobacteria bloom to brine shrimp and fish

The study indicated that all the implemented physicochemical parameters were suitable (ideal) for water productivity and fish production, but the blooming of $M$ aeriginosa in the first ponds group was thought to be the only reason for the increase in mortality, the low survival rates and low production. 
The result supported that of Carbis et al. (1996).

\section{REFERENCES}

Abdalla, A. A. F. (1997): Effects of increased nitrogen fertilization on water quality and yield of Nile tilapia, Oreochromis niloticus, and Common Carp, Cyprinus carpio, in earthen ponds in Egypt. Journal of Applied Aquaculture, 7(4):1 14 .

APHA (1985): Standard Methods for Examination of water and waste water, $16^{\text {th }}$ ed. American Public Health Association, Washington, D.C. $1268 \mathrm{pp}$.

AOAC (1990): Official Methods of Analysis of Association of Official Analytical Chemists, 15th edn. AOAC, Arlington, VA, $1298 \mathrm{pp}$.

Boon, P. I.; Bunn, S.E.; Green, J. D.; Shiel, R. J. (1994): Consumption of cyanobacteria by fresh-water zooplanktonimplications for the success of top-down control of cyanobacterial blooms in Australia. Aust. J. Mar. Fresh Res. 45:875-887.

Boyd, C. E. (1990): Water Quality in Ponds for Aquaculture. Alabama Agricultural Experiment Station, Auburn University, Birmingham Publishing.

Boyd, C. E. (1992): Shrimp pond bottom soil and sediment management. Pages 166-181 in J. Wyban, editor. Proceedings of the Special Session on Shrimp Farming. World Aquaculture
Society, Baton Rouge, Louisiana, USA.

Carbis, C.R.; Mitchell, G.F.; Anderson, J.W. and Mc Cauley, I. (1996): The effects of microcystins on the serum biochemistry of carp, Cyprinus carpio L., when the toxins are administered by gavages, immersion and intra-peritoneal routes. Journal of Fish Diseases 19:151-159.

Carbis, C.R.; Rawlin, G.T.; Grant, P.; Mitchell, G.F.; Anderson, J.W. and McCauley, I. (1997): A study of feral carp, Cyprinus carpio L., exposed to Microcystis aeruginosa at Lake Mokoan, Australia, and possible implications for ${ }^{\circledR} \mathrm{sh}$ health. Journal of Fish Diseases 20, 8191.

Carmichael, W.W. (1995): The toxins of cyanobacteria. Sci. Am. Jan. 270, 78-86.

Carmichael, W.W. and An, J. S. (1999): Using an enzyme linked immunosorbent assay (ELISA) and a protein phosphatase inhibition assay (PPIA) for the detection of microcystins and nodularins. Nat. Toxins 7:377385.

Christoffersen, K. (1996): Effect of microcystin on growth of single species and on mixed natural populations of heterotrophic nanoflagellates. Nat. Toxins 4:215-220.

De Bernardi, R. and Giussani, G. (1990): Are blue-green algae a suitable food for zooplankton? 
An overview. Hydrobiologia 200/201, 29-41.

Dianna, J.S., Lin, C.K., and Schneeberger, P.J., (1991): Relationships among nutrient inputs, Water nutrient concentrations primary production, and yield of Oreochromis niloticus in ponds, Aquaculture, 92,323,1991.

Gan N, Mi L, Sun X, Dai G, Chung, F.L, Song, L (2010) Sulforaphane protects Microcystin-LR-induced toxicity through activation of the Nrf2-mediated defensive response. Toxicol Appl Pharmacol 247:129-137

Geng, H. and Xie, P. (2008): Experimental studies on the effects of toxic Microcystis aeruginosa PCC7820 on the survival and reproduction of two freshwater rotifers Brachionus calyciflorus and Brachionus rubens. Ecotoxicology 17:709715

Ghadouani, A.; Pinel-Alloul, B. and Prepas, E. E., (2003): Effects of experimentally induced cyanobacterial blooms on crustacean zooplankton communities. Freshwater Biol. 48:363-381.

Golueke, C. G. (1977): Biological reclamation of solid wastes. Rodale Press, Pennsylvania, USA.

Hairston, Jr. M. G., Holtmeier, C. L.; Lampert, W.; Weider, L. J.; Post, D. M.; Fisher, J. M.; Caceres, C. E.; Fox, J. A. and Gaedke, U. (2001): Natural selection for grazer resistance to toxic cyanobacteria: evolution of phenotypic plasticity. Evolution, 55: 2203-2214.

Hallegraef, G.M., (1993): A review of harmful algal blooms and their apparent global increase. Phycologia 32: 79-99.

Hanson, L.A.; Johansson, L. and Persson, L. (1987): Effect $s$ of fish Grazing on nutrient release and succession of primary producers. Limnol. Oceanogr., 32: 723-729.

Keshavanath, P., Beveridge, M. C. M., Baird, D. J., Lawton, L. A., Nimmo, A.. and Codd, G. A. (1994): The functional grazing response of a phytoplanktivorous fish Oreochromis niloticus to mixtures of toxic and non-toxic strains of the cyanobacterium Microcystis aeruginosa. Journal of Fish Biology, 45: 123-129.

Khalil, M. T. (1990): The physical and chemical environmental of lake Manzala, Egypt. Hydrobiologia 196: 193-199.

Krenkel, P.A. and Novotny, V. (1980): Water Quality Management. Academic Press, New York.

Lampert, W. (1987): Laboratory studies on zooplanktoncyanobacteria interactions derived from enclosure studies. N. Z. J. Mar Freshwater Res. 21: 483-490.

Lahti, K., J. Ahtiainen, J. Rapala, K. Sivonen and S. I. Niemela (1995): Assessment of rapid bioassay for detecting 
cyanobacterial toxicity. Lett. Appl. Microbiol. 21: 109-114.

Leonard, J. A. and Paerl, H. W. (2005): Zooplankton community structure, micro-zooplankton grazing impact, and session energy content in the St. Johns river system. Florida as influenced by the toxic Cyanobacterium

Cylindrospermopsis raciborskii. Hydrobiologia, 537: 89-97.

Meyer, B. N.; Ferrigni, N. R.; Putnam, J. E.; Jacobsen, L. B.; Nichols, D. E. and McLaughlin, J. L. (1982): Brine shrimp: a convenient general bioassay for active plant constituents. J. Med. Plant Res. 45: 31-34.

Newman, J. R. and Barrett, P. R. F. (1993): Control of Microcystis aeruginosa by decomposing barley straw. J. Aquatic Plant Man. 31:203- 206.

Northcote, T.G. (1988): Fish in the structure and function of freshwater ecosystems; a "topdown" view. Can. J. Aquatic. Sci., 45: 361-379.

Osami, Y.; Ohkubo, N.; Tomoku, N. and Okada, M., (1994): Effects of irradiance and temperature on photosynthetic activity of cyanobacterium Microcystis sp. Environ. Technol. 15: 389-394.

Paerl, H.W. (1988): Nuisance phytoplankton blooms in coastal, estuarine, and inland waters. Limnol. Oceanogr. 33:823-847.

Paerl, H.W.; Fulton, R. S., Moisander, P. H.; and Dyble, J.
(2001): Harmful freshwater algal blooms with an emphasis on cyanobacteria. Sci. World. 1:76113.

Penaloza, R.; Rojas, M., Vila, I. and Zambrano, F. (1990): Toxicity of a soluble peptide from Microcystis sp. to zooplankton and fish. Freshwater Biol 24:233240.

Piper, R.G.; McElwain, I.B.; Orme,L.E.; McCraren, J. P.; Fowler, L.G. and Leonard, J. R. (1982): Fish hatchery management. US Department Interior, fish and Wildlife Service, Washington, D.C.517 pp.

Qin, J. and Culver, D. A. (1992): The survival and growth of larval walleye, Stizostedion vitreum, and trophic dynamics in fertilized ponds. Aquaculture, 108: 257276.

Rohrlack, T.; Dittmann, E.; Henning, M., Borner, T. and Kohl, J. G. (1999): Role of microcystins in poisoning and food ingestion inhibition of Daphnia galeata caused by the cyanobacterium Microcystis aeruginosa. Appl. Environ. Microbiol. 65:737-739.

Sarnelle, O. and Wilson, A.E. (2005): Local adaptation of Daphnia pulicaria to toxic cyanobacteria. Limnol. Oceanogr. 50:1565-1570.

Sellner, K.G.; Brownlee, D.C.; Buundy, M. H.; Brownlkee, S.G.; Braun, K.R. (1993): Zooplankton grazing in a 
Potomac River cyanobacteria bloom. Estuaries 16, 859-872.

Sivonen, K. (1990): Effects of light, temperature, nitrate, orthophosphate, and bacteria on growth of and hepatotoxin production by Oscillatoria agardhii strains. Appl. Environ. Microbiol. 56:2658-2666.

Soares M. C. S.; Lurling, M.; Huszar, V. L. M. (2010): Responses of the rotifer Brachionus calyciflorus to two tropical toxic cyanobacteria (Cylindrospermopsis raciborskii and Microcystis aeruginosa) in pure and mixed diets with green algae. J Plankton Res. 32: 9991008.

Talling, J. F. (1986): The seasonality of phytoplankton in African lakes. Hydrobiologia, 138: 139-160.

Thostrup, L. and Christoffersen, K. (1999): Accumulation of microcystin in Daphnia magna feeding on toxic Microcystis. Archiv Fur Hydrobiologie, 145:447-467.

Trabeau, M.; Bruhn-Keup, R.; Mcdermott C.; Keomany, M.; Millsaps, A.; Emery, A. and De Stasio, JR. B. (2004): Midsummer decline of a Daphnia population attributed in part to cyanobacterial capsule production. J. Plankton Res. 26:949-961.

Vezie, C., F.; Benoufflla, K.; Sivonen, G. B. and Laplanche,
A. (1996): Detection of toxicity of cyanobacterial strains using Artemia salina and Microtox assays compared with mouse bioassay results. Phycologia. 35(Suppl.6):198-202.

Walls, M., LaurenMaatta, C., Ketola, M., Ohraho, P., Reinikainen, M. and Repka, S. (1997): Phenotypic plasticity of Daphnia life history traits: the roles of predation, food level and toxic cyanobacteria. Freshwater Biol. 38:353-364.

Watanabe, M. F., Harada K. I., Matsuura K., Watanabe M. and Suzuki, M. (1989): Heptapeptide toxin production during the culture of two microcystis species (Cyanobacteria). J. Appl. Phycol. 1:161-5.

Wylie, J. L. and Currie, D. J. (1991): The relative importance of bacteria and algae as food source for crustacean zooplankton. Limnol. Oceanogr, 36:708-728.

Yoshida, S.; Forno, D. A.; Cock, J. H. and Gomez, K. A. (1976): Laboratory manual for physiological studies of rice, 3rd edition. The International Rice Research Institute, Los Baiios, Laguna, Philippines.

Zar, J. H. (1984): Bio-statistical analysis, 2nd edition. PrenticeHall International, Inc. Englewood Cliffs, New Jersey, USA. 
Zhang, X. and Geng, H. (2011):

Effect of Microcystis aeruginosa on the rotifer Brachionus calyciflorus at different temperatures Bull Environ. Contam. Toxicol, Nov 6. [Epub ahead of print].

Table (2): The total average values of different water quality parameters in water fish ponds in first group ponds (affected) and second group ponds (un-affected) by Microcystis aeraginosa

\begin{tabular}{|c|c|c|}
\hline parameters & first group ponds & second group ponds \\
\hline Temperature $\left({ }^{\circ} \mathbf{C}\right)$ & $27.77 \mathrm{~A} \pm 2.12$ & $28.93 \mathrm{~A} \pm 2.01$ \\
\hline pH Value & $8.74 \mathrm{~A}+0.29$ & $8.54 \mathrm{~A} \pm 0.32$ \\
\hline Secchi disk (SD cm) & $18.08 \mathrm{~B} \pm 1.4$ & $25.13 \mathrm{~A} \pm 1.5$ \\
\hline Dissolved Oxygen (mg/l) & $9.6 \mathrm{~A} \pm 1.43$ & $7.8 \mathrm{~B} \pm 1.4$ \\
\hline Electric conductivity & $969.04 \mathrm{~A} \pm 0.178$ & $1065.47 \mathrm{~A} \pm 0.271$ \\
\hline Salinity ( mg/l) & $0.047 \mathrm{~B} \pm 0.01$ & $0.31 \mathrm{~A} \pm 0.08$ \\
\hline Chlorophyll "a("Ug/l) & $88.48 .28 \mathrm{~A} \pm 120$ & $56.97 .92 \mathrm{~A} \pm 123.14$ \\
\hline Total suspended solid (mg/l) & $0.958 \mathrm{~A} \pm 0.673$ & $0.753 \mathrm{~B} \pm 0.637$ \\
\hline Ammonia $\left(\mathrm{NH}_{4} \mathrm{mg} / \mathrm{l}\right)$ & $0.416 \mathrm{~B} \pm 0.2$ & $0.717 \mathrm{~A} \pm 0.2$ \\
\hline Nitra rate $\left(\mathrm{NO}_{3} \mathrm{mg} / \mathrm{l}\right)$ & $1.8 \mathrm{~A} \pm 0.447$ & $1.71 \mathrm{~A} \pm 0.0428$ \\
\hline Total Phosphorus ( mg/l) & $0.711 \mathrm{~B} \pm 1.63$ & $1.049 \mathrm{~A} \pm 1.1842$ \\
\hline Alkalinity (mg/l) & $258.33 \mathrm{~B} \pm 16$ & $284.82 \mathrm{~A} \pm 7$ \\
\hline Hardness (mg/l) & $253 \mathrm{~A} \pm 11$ & $231 \mathrm{~A} \pm 17$ \\
\hline Total Phytoplankton (No/l) & $2396480.0 \mathrm{~A} \pm 9574$ & $479195.8 \mathrm{~B} \pm 7863$ \\
\hline Total zooplankton (No/l) & $2803625 \mathrm{~A} \pm 10551$ & $2564880 \mathrm{~A} \pm 9401$ \\
\hline
\end{tabular}

- Data are represented as means \pm standard error.

- Values with the same letters show non-significant differences between the two groups and values with the different letters show significant differences at $(\mathrm{p}<0.05)$ 
Table 3: Variation of the total numbers of Phytoplankton groups (Number of organisms /L) and Microcystis aeraginosa numbers number of cells /l) and percentage from total count of phytoplankton in water of first group ponds (affected) and second group ponds (unaffected) by Microcystis aeraginosa

\begin{tabular}{|c|c|c|c|c|c|c|c|c|c|c|c|c|c|c|}
\hline & \multicolumn{4}{|c|}{ CYANOPHYCOPHYTA } & \multirow{2}{*}{\multicolumn{2}{|c|}{ BACILAROPHYTA }} & \multirow{2}{*}{\multicolumn{2}{|c|}{ EUGLENOPHYTA }} & \multirow{2}{*}{\multicolumn{2}{|c|}{ CHLOROPHYTA }} & \multirow{2}{*}{\multicolumn{2}{|c|}{ TOTAL PHYTO }} & \multirow{2}{*}{\multicolumn{2}{|c|}{$\begin{array}{c}\% \\
\text { M.aeraginosa }\end{array}$}} \\
\hline & \multicolumn{2}{|c|}{$\begin{array}{c}\text { without } \\
\text { M.aeraginosa }\end{array}$} & \multicolumn{2}{|c|}{ M.aeraginosa } & & & & & & & & & & \\
\hline & $\begin{array}{l}\text { First } \\
\text { group } \\
\text { ponds }\end{array}$ & $\begin{array}{l}\text { Second } \\
\text { group } \\
\text { ponds }\end{array}$ & $\begin{array}{l}\text { First } \\
\text { group } \\
\text { ponds }\end{array}$ & $\begin{array}{l}\text { Second } \\
\text { group } \\
\text { ponds }\end{array}$ & $\begin{array}{l}\text { First } \\
\text { group } \\
\text { ponds }\end{array}$ & $\begin{array}{l}\text { Second } \\
\text { group } \\
\text { ponds }\end{array}$ & $\begin{array}{l}\text { First } \\
\text { group } \\
\text { ponds }\end{array}$ & $\begin{array}{l}\text { Second } \\
\text { group } \\
\text { ponds }\end{array}$ & $\begin{array}{l}\text { First } \\
\text { group } \\
\text { ponds }\end{array}$ & $\begin{array}{l}\text { Second } \\
\text { group } \\
\text { ponds }\end{array}$ & $\begin{array}{l}\text { First } \\
\text { group } \\
\text { ponds }\end{array}$ & $\begin{array}{l}\text { Second } \\
\text { group } \\
\text { ponds }\end{array}$ & $\begin{array}{l}\text { First } \\
\text { group } \\
\text { ponds }\end{array}$ & $\begin{array}{c}\begin{array}{c}\text { Secon } \\
\text { d }\end{array} \\
\text { group } \\
\text { ponds }\end{array}$ \\
\hline May & $\begin{array}{l}4400 \mathrm{~B} \\
\pm 400\end{array}$ & $\begin{array}{c}25700 \mathrm{~A} \\
\pm 819\end{array}$ & $\begin{array}{l}79300 \mathrm{~A} \\
\pm 4051\end{array}$ & $\begin{array}{l}9000 \mathrm{~B} \\
\pm 61\end{array}$ & $\begin{array}{l}9900 \mathrm{~B} \\
\pm 900\end{array}$ & $\begin{array}{c}12400 \mathrm{~A} \\
\pm 980\end{array}$ & $\begin{array}{c}105600 \mathrm{~A} \\
\pm 1000\end{array}$ & $\begin{array}{l}56360 \mathrm{~B} \\
\pm 48941\end{array}$ & $\begin{array}{l}51000 \mathrm{~B} \\
\pm 374\end{array}$ & $\begin{array}{c}98640 \mathrm{~A} \\
\pm 849\end{array}$ & $\begin{array}{l}250200 \mathrm{~A} \\
\pm 2743\end{array}$ & $\begin{array}{c}202100 \mathrm{~A} \\
\pm 1129\end{array}$ & 31.7 & 4.5 \\
\hline June & $\begin{array}{c}535290 \mathrm{~A} \\
\pm 4400\end{array}$ & $\begin{array}{l}47520 \mathrm{~B} \\
\pm 8198\end{array}$ & $\begin{array}{c}580000 \mathrm{~A} \\
\pm 4051\end{array}$ & $\begin{array}{l}2560 \mathrm{~B} \\
\pm 361\end{array}$ & $\begin{array}{c}55510 \mathrm{~B} \\
\pm 990\end{array}$ & $\begin{array}{l}70760 \mathrm{~A} \\
\pm 906\end{array}$ & $\begin{array}{c}226060 \mathrm{~A} \\
\pm 1050\end{array}$ & $\begin{array}{l}79760 \mathrm{~B} \\
\pm 4841\end{array}$ & $\begin{array}{c}319720 \mathrm{~B} \\
\pm 3474\end{array}$ & $\begin{array}{c}509120 \mathrm{~A} \\
\pm 488\end{array}$ & $\begin{array}{c}6936580 \mathrm{~A} \\
\pm 2743\end{array}$ & $\begin{array}{l}709720 \mathrm{~B} \\
\pm 112691\end{array}$ & 83.6 & 0.4 \\
\hline July & $\begin{array}{l}665100 \mathrm{~A} \\
\pm 162576\end{array}$ & $\begin{array}{l}52280 \mathrm{~B} \\
\pm 18421\end{array}$ & $\begin{array}{l}69400 \mathrm{~A} \\
\pm 1598\end{array}$ & $\begin{array}{l}5640 \mathrm{~B} \\
\pm 5.680\end{array}$ & $\begin{array}{l}11240 \mathrm{~B} \\
\pm 972\end{array}$ & $\begin{array}{c}68420 \mathrm{~A} \\
\pm 292\end{array}$ & $\begin{array}{c}255200 \mathrm{~A} \\
\pm 1938\end{array}$ & $\begin{array}{l}48720 \mathrm{~B} \\
\pm 242\end{array}$ & $\begin{array}{c}150320 \mathrm{~B} \\
\pm 683\end{array}$ & $\begin{array}{c}506740 \mathrm{~A} \\
\pm 1133\end{array}$ & $\begin{array}{c}1775860 \mathrm{~A} \\
\pm 2771\end{array}$ & $\begin{array}{c}681800 \mathrm{~B} \\
\pm 1089\end{array}$ & 39.1 & 0.8 \\
\hline August & $\begin{array}{l}405480 \mathrm{~B} \\
\pm 117276\end{array}$ & $\begin{array}{l}49400 \mathrm{~A} \\
\pm 17623\end{array}$ & $\begin{array}{l}46600 \mathrm{~A} \\
\pm 2679\end{array}$ & $\begin{array}{l}1000 \mathrm{~B} \\
\pm 0.520\end{array}$ & $\begin{array}{c}99780 \mathrm{~A} \\
\pm 318\end{array}$ & $\begin{array}{l}73100 \mathrm{~B} \\
\pm 886\end{array}$ & $\begin{array}{c}196920 \mathrm{~A} \\
\pm 4896\end{array}$ & $\begin{array}{l}110800 \mathrm{~B} \\
\pm 3560\end{array}$ & $\begin{array}{c}489120 \mathrm{~A} \\
\pm 1378\end{array}$ & $\begin{array}{l}511500 \mathrm{~A} \\
\pm 975\end{array}$ & $\begin{array}{c}1657300 \mathrm{~A} \\
\pm 1956\end{array}$ & $\begin{array}{c}745800 \mathrm{~B} \\
\pm 2584\end{array}$ & 28.1 & 0.1 \\
\hline September & $\begin{array}{c}676540 \mathrm{~A} \\
\pm 1575\end{array}$ & $\begin{array}{c}67860 \mathrm{~A} \\
\pm 237\end{array}$ & $\begin{array}{c}1982000 \\
\text { A } \\
\pm 9451\end{array}$ & $\begin{array}{l}5900 \mathrm{~B} \\
\pm 4605\end{array}$ & $\begin{array}{c}27260 \mathrm{~B} \\
\pm 285\end{array}$ & $\begin{array}{c}47260 \mathrm{~A} \\
\pm 381\end{array}$ & $\begin{array}{c}153920 \mathrm{~A} \\
\pm 553\end{array}$ & $\begin{array}{c}11720 \mathrm{~B} \\
\pm 932\end{array}$ & $\begin{array}{c}177440 \mathrm{~B} \\
\pm 395\end{array}$ & $\begin{array}{c}210240 \mathrm{~A} \\
\pm 8259\end{array}$ & $\begin{array}{l}3017160 \mathrm{~A} \\
\pm 239498\end{array}$ & $\begin{array}{l}275120 \mathrm{~B} \\
\pm 100671\end{array}$ & 65.7 & 2.1 \\
\hline October & $\begin{array}{c}340470 \mathrm{~A} \\
\pm 608\end{array}$ & $\begin{array}{c}39330 \mathrm{~A} \\
\pm 129\end{array}$ & $\begin{array}{c}138750 \mathrm{~A} \\
\pm 3365\end{array}$ & $\begin{array}{c}2995 \mathrm{~B} \\
\pm 30\end{array}$ & $\begin{array}{c}18580 \mathrm{~B} \\
\pm 229\end{array}$ & $\begin{array}{l}2983 \mathrm{~A} \\
\pm 156\end{array}$ & $\begin{array}{c}129760 \mathrm{~A} \\
\pm 748\end{array}$ & $\begin{array}{c}34040 \mathrm{~A} \\
\pm 271\end{array}$ & $\begin{array}{r}114220 \mathrm{~B} \\
\pm \quad 2426\end{array}$ & $\begin{array}{c}154440 \mathrm{~A} \\
\pm 1767\end{array}$ & $\begin{array}{c}741780 \mathrm{~A} \\
\pm 2300\end{array}$ & $\begin{array}{c}260635 \mathrm{~B} \\
\pm 1638\end{array}$ & 18.7 & 1.1 \\
\hline
\end{tabular}

- Data are represented as means \pm standard error.

- $\quad \%$ of Microcystis aeraginosa = means numbers of Microcystis aeraginosa / means numbers of total phytoplankton x 100

- Values with the same letters show non-significant differences between the two groups and values with the different letters show significant differences at $(\mathrm{p}<0.05)$ 
Table (4): Variation and distribution of zooplankton (\%) in water fishponds in first group ponds (affected) and second group ponds (unaffected) by Microcystis aeraginosa

\begin{tabular}{ccccccccc}
\hline & \multicolumn{2}{c}{ CLADOSRA\% } & \multicolumn{2}{c}{ ROTIFER \% } & \multicolumn{2}{c}{ COPEPODA\% } & \multicolumn{2}{c}{ TOTALZOO\% } \\
\hline & $\begin{array}{c}\text { First } \\
\text { group }\end{array}$ & $\begin{array}{c}\text { Second } \\
\text { group }\end{array}$ & $\begin{array}{c}\text { First } \\
\text { group }\end{array}$ & $\begin{array}{c}\text { Second } \\
\text { group }\end{array}$ & $\begin{array}{c}\text { First } \\
\text { group }\end{array}$ & $\begin{array}{c}\text { Second } \\
\text { group }\end{array}$ & $\begin{array}{c}\text { First } \\
\text { group }\end{array}$ & $\begin{array}{c}\text { Second } \\
\text { group }\end{array}$ \\
\hline May & 6.0 & 28.3 & 11.3 & 37.1 & 82.7 & 34.6 & 100.0 & 100.0 \\
June & 59.8 & 1.2 & 10.6 & 98.0 & 29.6 & 0.9 & 100.0 & 100.0 \\
July & 0.3 & 0.0 & 6.1 & 69.7 & 93.6 & 30.3 & 100.0 & 100.0 \\
August & 46.4 & 7.5 & 44.5 & 90.7 & 9.1 & 1.8 & 100.0 & 100.0 \\
September & 1.6 & 0.0 & 67.5 & 50.0 & 30.9 & 50.0 & 100.0 & 100.0 \\
October & 12.5 & 3.4 & 8.2 & 91.2 & 79.3 & 5.4 & 100.0 & 100.0 \\
Total average\% & 21.1 & 6.7 & 24.7 & 72.8 & 54.2 & 20.5 & 100.0 & 100 \\
\hline
\end{tabular}

- Cladosra\% = means numbers of Cladosra / means numbers of total zooplankton x 100

- Rotifer $\%=$ means numbers of Rotifer / means numbers of total zooplankton x 100

- Copepoda $\%=$ means numbers of Copepoda / means numbers of total zooplankton $\mathrm{x} 100$

Table 5: Variation of the total numbers of zooplankton (Number of organisms /l) in water fishponds in first group ponds (affected) and second group ponds (unaffected) by Microcystis aeraginosa

\begin{tabular}{|c|c|c|c|c|c|c|c|c|}
\hline & \multicolumn{2}{|c|}{ CLADOSRA } & \multicolumn{2}{|c|}{ ROTIFERA } & \multicolumn{2}{|c|}{ COPEPODA } & \multicolumn{2}{|c|}{ TOTALZOO } \\
\hline & $\begin{array}{l}\begin{array}{l}\text { First } \\
\text { group }\end{array} \\
\end{array}$ & $\begin{array}{l}\text { Second } \\
\text { group }\end{array}$ & $\begin{array}{l}\text { First } \\
\text { group }\end{array}$ & $\begin{array}{l}\text { Second } \\
\text { group }\end{array}$ & $\begin{array}{l}\text { First } \\
\text { group }\end{array}$ & $\begin{array}{l}\text { Second } \\
\text { group }\end{array}$ & $\begin{array}{l}\text { First } \\
\text { group }\end{array}$ & $\begin{array}{l}\text { Second } \\
\text { group }\end{array}$ \\
\hline \multirow{2}{*}{ May } & 1200.0B & $2185.0 \mathrm{~A}$ & 2276.7B & $2863.3 \mathrm{~A}$ & 16666.7A & 2676.7B & 20143.3A & $7725.0 \mathrm{~B}$ \\
\hline & \pm 103.3 & \pm 1477.2 & \pm 0.00 & \pm 114.2 & \pm 945.3 & \pm 1048.3 & \pm 108.2 & \pm 788.6 \\
\hline \multirow{2}{*}{ June } & $8408.3 \mathrm{~A}$ & 901.7B & 1485.0B & $76255.0 \mathrm{~A}$ & 4161.7A & $681.7 \mathrm{~B}$ & 14055.0B & 77838.3A \\
\hline & \pm 351.5 & \pm 584.98 & \pm 120.4 & \pm 292.9 & \pm 335.4 & \pm 352.3 & \pm 259.2 & \pm 892.0 \\
\hline \multirow{2}{*}{ July } & $118.3 \mathrm{~A}$ & $0.0 \mathrm{~B}$ & 2663.3B & $3483.3 \mathrm{~A}$ & $40950.0 \mathrm{~A}$ & 1516.7B & 43731.7A & $5000.0 \mathrm{~B}$ \\
\hline & \pm 11.3 & \pm 0.00 & \pm 660.6 & \pm 857.0 & \pm 223.2 & \pm 151.7 & \pm 396.8 & \pm 117.7 \\
\hline \multirow{2}{*}{ August } & $15110.0 \mathrm{~A}$ & 2333.3B & 14481.7B & $28058.3 \mathrm{~A}$ & 2966.7A & $550.0 \mathrm{~B}$ & $32558.3 \mathrm{~A}$ & 30941.7A \\
\hline & \pm 71.01 & \pm 1760.8 & \pm 451.0 & \pm 1151.8 & \pm 1407.2 & \pm 250.3 & \pm 900.5 & \pm 594.1 \\
\hline September & $\begin{array}{c}520.0 \mathrm{~A} \\
\pm 30.6\end{array}$ & $\begin{array}{l}0.0 \mathrm{~B} \\
\pm 0.0\end{array}$ & $\begin{array}{c}21430.0 \mathrm{~A} \\
\pm 624.3\end{array}$ & $\begin{array}{c}1100.0 \mathrm{~B} \\
\pm 0.0\end{array}$ & $\begin{array}{c}9802.5 \mathrm{~A} \\
\pm 387.0\end{array}$ & $\begin{array}{c}1100.0 \mathrm{~B} \\
\pm 0.0\end{array}$ & $\begin{array}{c}31752.5 \mathrm{~A} \\
\pm 787.0\end{array}$ & $\begin{array}{c}2200.0 \mathrm{~B} \\
\pm 0.0\end{array}$ \\
\hline October & $\begin{array}{c}3242.2 \mathrm{~A} \\
\pm 54.4\end{array}$ & $\begin{array}{c}1028.9 \mathrm{~B} \\
\pm 68.4\end{array}$ & $\begin{array}{c}2141.7 \mathrm{~B} \\
\pm 127.1\end{array}$ & $\begin{array}{c}27533.9 \mathrm{~A} \\
\pm 7996.7\end{array}$ & $\begin{array}{c}20592.8 \mathrm{~A} \\
\pm 181.3\end{array}$ & $\begin{array}{c}1625.0 \mathrm{~B} \\
\pm 97.4\end{array}$ & $\begin{array}{c}25976.7 \mathrm{~B} \\
\pm 151.4\end{array}$ & $\begin{array}{c}30187.8 \mathrm{~A} \\
\pm 932.8\end{array}$ \\
\hline
\end{tabular}

Data are represented as means \pm standard error

Values with the same letters show non-significant differences between the two groups and values with the different letters show significant differences at $(\mathrm{p}<0.05)$ 
Effect of Microcystis aeruginosa blooming on the production of Nile tilapia (Oreochromis niloticus) in fish ponds

Table (6): Survival rate and fish production in first group ponds (affected) and second group ponds (unaffected) by Microcystis a eraginosa

\begin{tabular}{ccccc}
\hline Pond & \multicolumn{2}{c}{ First group ponds } & \multicolumn{2}{c}{ Second group ponds } \\
\cline { 2 - 5 } Numbers & Survival \% & Production $/ \mathbf{k g}$ & Survival \% & Production /kg \\
\hline 1 & 12.1 & 67.76 & 89.3 & 571.52 \\
2 & 6.8 & 38.08 & 92.4 & 591.36 \\
3 & 1.6 & 8.96 & 74.9 & 479.36 \\
4 & 3.7 & 20.72 & 99.4 & 636.16 \\
5 & 3 & 16.8 & 85 & 544 \\
6 & 6.1 & 34.16 & 84.7 & 542.08 \\
\hline
\end{tabular}

Table (7): Percentage of $\mathrm{LC}_{50}$ death of Artemia at 24 hours exposed to the toxicity threshold concentration, expressed as dry weight of Microcystis aeraginosa

\begin{tabular}{lccccc}
\hline & \multicolumn{5}{c}{ Percentage of death of Artemia at $24 \mathrm{hour}$} \\
\hline Dry wt $\mathrm{mg} / \mathrm{ml}$ & $100 \mathrm{mg} / \mathrm{ml}$ & $50 \mathrm{mg} / \mathrm{ml}$ & $20 \mathrm{mg} / \mathrm{ml}$ & $10 \mathrm{mg} / \mathrm{ml}$ & $2 \mathrm{mg} / \mathrm{ml}$ \\
Time/ hours & 1 & 4 & 12 & 18.5 & 24 \\
Percentage & 100 & 100 & 79 & 38 & 0 \\
\hline
\end{tabular}
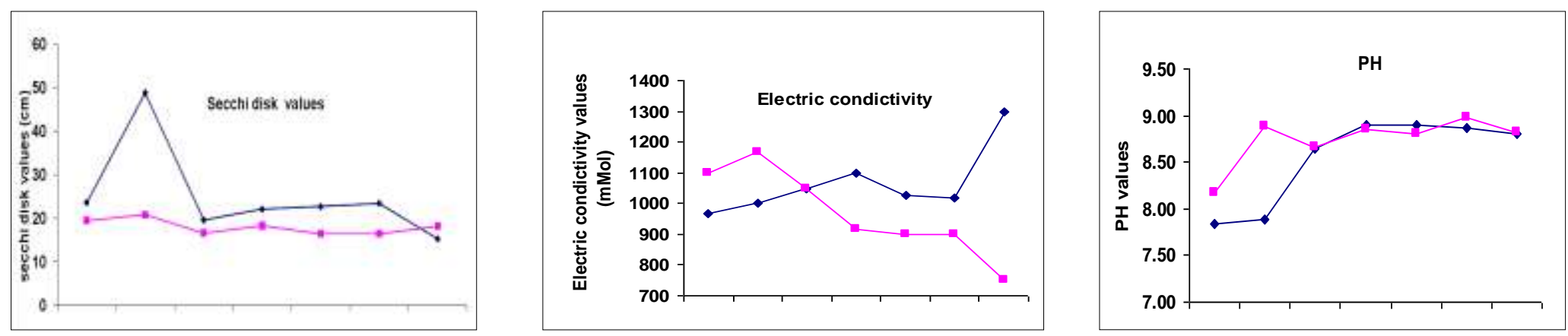
Elgammal M. A. and Ramadan A. A.
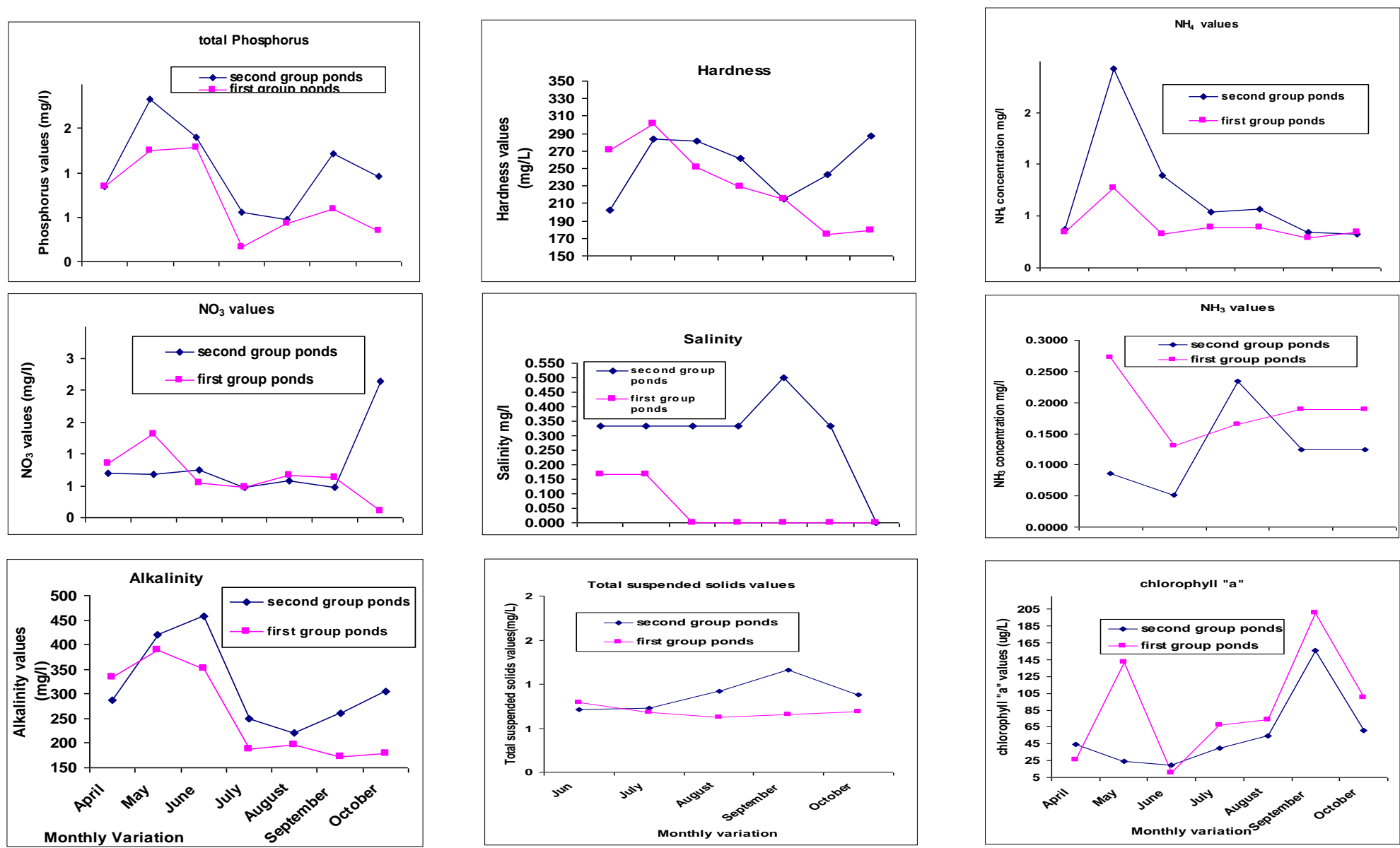

Figures 1: Water quality parameters changed (secchi disk, electric conductivity, $\mathrm{pH}$, total phosphorus, hardness, alkalinity, $\mathrm{NO}_{3}$, salinity, $\mathrm{NH}_{3}, \mathrm{NH}_{4}$, , total suspended solids and chlorophyll "a" in water fish ponds in first group ponds (affected) and second group ponds (unaffected) by Microcystis aeraginosa 


\section{تأثير وفرة طحلب الميكرو سيست أوريجينوزا على الأنتاج السمكي للبلطي في المزارع

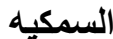

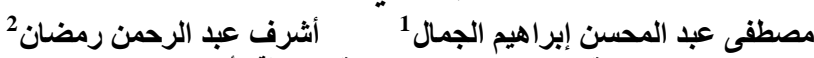

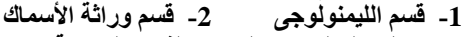 \\ بالمعمل المركزى لبحوث الثروة المبمية}

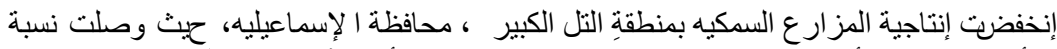

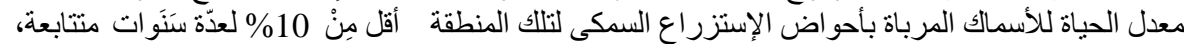

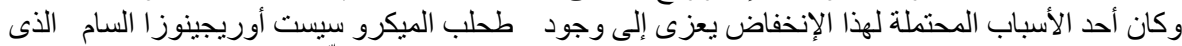

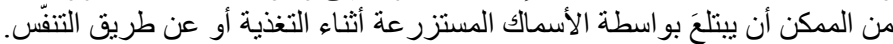

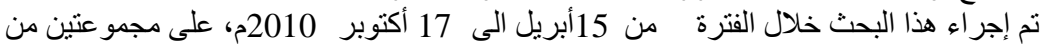

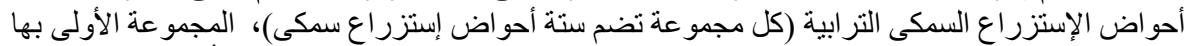

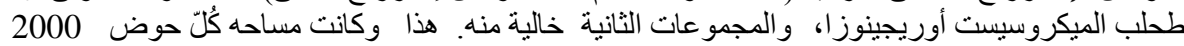

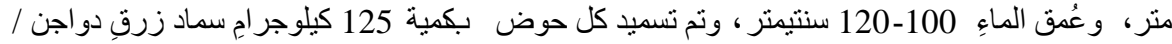

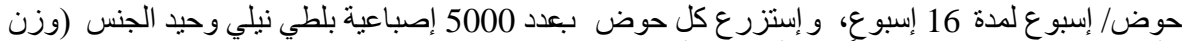

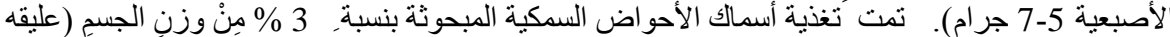

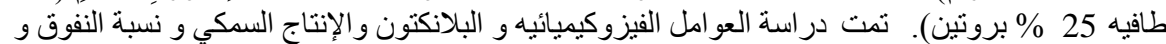

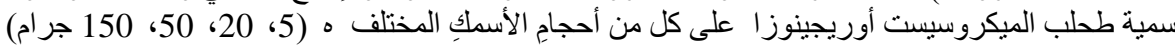

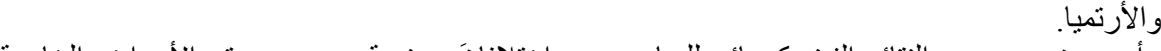

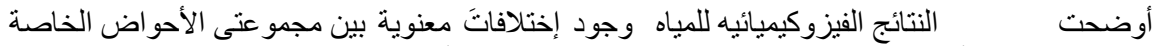

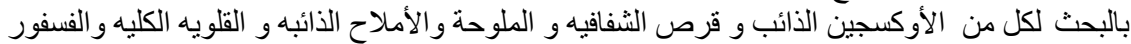

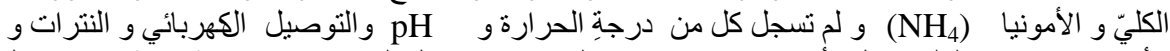
الأمّونيا ( ${ }^{2}$ و الامونيا

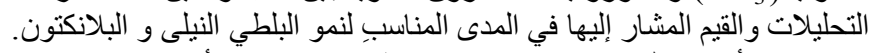

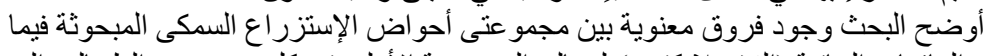

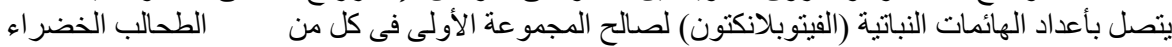

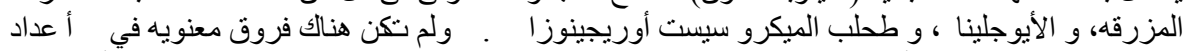

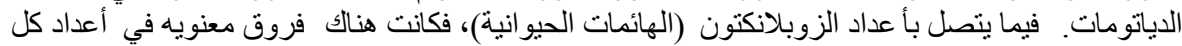

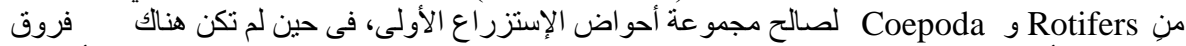

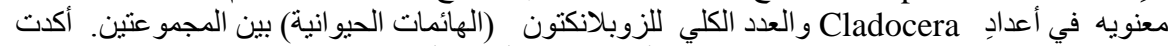

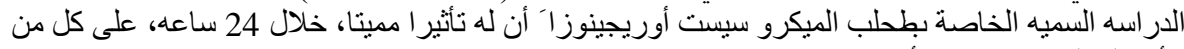
الأسماك المستزر عة و الأرتيميا.

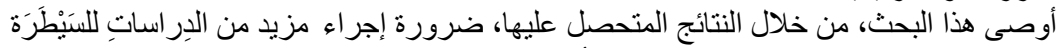

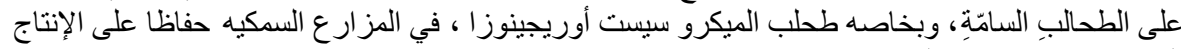
السمكى و الإستثمار ات الخاصة بهـ. 